\title{
Nutritional and Antinutritional Properties of lindur (Bruguiera gymnorrhiza)Fruits Flour from Different Pre-Treatments
}

by Eko Nurcahya Dewi, Retno Ayu Kurniasih, Lukita Purnamayati

Submission date: 09-Oct-2018 12:37 AM (UTC+0700)

Submission ID: 1016119897

File name: TANIN_BRUGUIRERA.pdf (85.07K)

Word count : 3323

Character count: 16770 


\title{
Nutritional and Antinutritional Properties of lindur (Bruguiera gymnorrhiza) Fruits Flour from Different Pre-Treatments
}

Eko Nurcahya Dewi*, Retno Ayu Kurniasih, and Lukita Purnamayati

Department of Fisheries Technology, Faculty of Fisheries and Marine Science, Diponegoro University, Semarang, 50275, Indonesia

\begin{abstract}
Background: lindur (Bruguiera sp) fruits are rich in nutrition and bioactive compound 10 ut also had several anti-nutritional factors like tannins, saponins, and hydrogen cyanide (HCN). The aim of this study was to investigate the effect of pre-treatments on the preparation of lindur fruits flour to the nutritional and antinutritional properties, and to investigate the best pre-treatment to decrease the antinutritional properties in lindur fruit flour. Method: The pre-treatments were conducted by soaking the fruit in water, saturated salt solution, $\mathrm{CaCO}_{3}$ solution, and rice husk ash solution. Nutrition of lindur flour was determined in terms of proximate composition and crude fiber. Antinutritional factors of the lindur flour were determined of tannin, saponin, and hydrogen cyanide (HCN). Results: Pre-treatment decreased the moisture content but increased protein, lipid, carbohydrate, and crude fiber of lindur flour. By soaking into saturated salt, nutrition could produce lowest moisture yet highest protein, carbohydrate, and crude fiber content. Pre-treatment with soaking into saturated salt solution also showed the higher reduction of tannin and $\mathrm{HCN}$ content compared to soaking into water, $\mathrm{CaCO}_{3}$ solution, and rice husk ash solution. The lindur fruits flour soaking into saturated salt solution has a tannin content $(0.766 \pm 0.070) \%$ and $\mathrm{HCN}$ content $(231.705 \pm 6.004) \mathrm{ppm}$. Meanwhile, pre-treatment by soaking in water, saturated salt solution, and $\mathrm{CaCO}_{3}$ solution did not affect the saponin content of lindur flour. Conclusion: Different soaking method affects the nutritional value and antinutritional properties of lindur flour. The soaking treatment into saturated salt solution was the best pre-treatment method.
\end{abstract}

Keywords: Antinutritional, lindur, Nutritional, Pre-Treatments.

\section{INTRODUCTION}

Mangrove forests are widely spread in the coastal areas of Indonesia, nearly $25 \%$ of the world's mangrove forests. lindur (Burguiera gymnorrhiza) is one of the mangrove species found in Indonesia.' lindur fruits have long beans that can be used for human consumption and as a traditional medicine. The high carbohydrate content of the lindur fruits make the fruits become a new food source. ${ }^{2-5}$ Although lindur fruits are rich in bioactive compound, but their use in food is still limited because of the presence of several antinutritional factors like tannins, saponins, and hydrogen cyanide $(\mathrm{HCN})$.

Tannins are phenolic compounds that can interfere with iron absorption in the gastro-intestinal tract, thus decreasing the bioavailability of iron. Tannins are responsible for the taste of food and drinks. ${ }^{6-8}$ Saponin has a bitter taste to form a stable foam in water, and cannot be removed with the addition of acid. Some saponin is toxic and known as sapotoxin. ${ }^{9-11}$ While $\mathrm{HCN}$

*Author to whom correspondence should be addressed. is responsible for tissue hypoxia. Exposure of $\mathrm{HCN}$ causes respiratory cardiovascular, neurological, and thyroid defects. ${ }^{12}$ These toxic factors present in lindur fruits must be removed or reduced in order to utilize its entire nutritional potential.

The methods for reduction of antinutritional factors of a food source can be done through a heating process. Antinutritional factors of the food source are unstable to heat, so it can be reduced with heat treatments and the use of chemicals, such as hydrochloric acid, acetic acid, and calcium hydroxide. ${ }^{13}$

The community of the northern coast of Jawa island, Indonesia, has been consuming this fruit for a long time. They soaked the fruit in water and rice husk ash solution before processing. Therefore, further study is needed to determine the different soaking solutior 9 ward the nutritional and antinutritional value of lindur flour. The aim of this study was to investigate the effect of pre-treatments on preparation lindur fruit flour to the nutritional and antinutritional properties and also to investigate the best pre-treatment to reduce the antinutritional properties of lindur fruit flour. In this study, the lindur fruits were soaked in water, saturated salt solution, $\mathrm{CaCO}_{3}$ solution, and rice husk 
ash solution for pre-treatments on preparation lindur fruits flour. The proximate composition, crude fiber, tannin content, saponin content, and $\mathrm{HCN}$ content of lindur fruits flour were analyzed.

\section{METHOD}

\subsection{Material}

The lindur (Bruguiera gymnorrhiza) fruits from the north coast of Kendal, Central Java, Indonesia, were used as a primary raw material. Water, saturated salt solution, $\mathrm{CaCO}_{3}$ solution, and rice husk ash solution were used as reducing agent of antinutritional factors.

\subsection{Lindur Fruits Flour Preparation}

The lindur fruits were peeled and boiled at $100{ }^{\circ} \mathrm{C}$ in an aqueous solution for an hour. Each of samples was treated randomly to four different treatments were soaked on water $\left(A_{1}\right)$, saturated salt solution $\left(A_{2}\right), \mathrm{CaCO}_{3}$ solution $\left(A_{3}\right)$, and rice husk ash solution $\left(A_{4}\right)$. The fresh lindur fruits were used as control $\left(A_{0}\right)$. Each of solutions made with the ratio of material (salt, $\mathrm{CaCO}_{3}$, and rice husk ash) and distilled water of 1:10 (w/v). The fruits were soaked in the four different solutions for 72 hours with a ratio $1: 3(w / v)$. After finished soaking, the fruits are sliced, dried, and then were ground with a miller 80 in mesh size.

\subsection{Proximate Composition and Crude Fiber}

The proximate composition (moisture, protein, lipid, ash, and carbohydrate content) and crude fiber of lindur fruits flour were carried out in triplicate using the methods described by AOAC. ${ }^{14}$

\subsection{Tannin Content}

Lindur fruit flour $(1,5 \mathrm{~g})$ was added $50 \mathrm{~mL}$ of aquadest at $60^{\circ} \mathrm{C}$ and set aside for 30 minutes. The sample solution was filtered and aquadest was added until $250 \mathrm{ml}$. The sample $(25 \mathrm{~mL})$ was added $20 \mathrm{~mL}$ of indigocarmin solution and titrated using $\mathrm{KmnO}_{4}$ $0,1 \mathrm{~N}$ solution until the royal blue fades to a light green. Then drop-wise titration until the lime green changes to yellow. The titrant volume needed was noted as $A \mathrm{~mL}$.

The blank titration using $25 \mathrm{~mL}$ aquades was added $20 \mathrm{~mL}$ of indigocarmin solution. This titrant volume noted as $B \mathrm{~mL}$. The tannin content calculated using formula. ${ }^{1,6}$

$$
\text { Tanin content }(\%)=\frac{(10(A-B) \times N \times 0.00416)}{\text { Sample }(\mathrm{g})} \times 100 \%
$$

\subsection{Saponin Content}

The lindur fruits flour $(20 \mathrm{~g})$ were put into a conical flask and $100 \mathrm{ml}$ of $20 \%$ ethanol was added. The samples were heated with a hot water bath for $4 \mathrm{~h}$ with continuous stirring at $55{ }^{\circ} \mathrm{C}$. The solution was filtered and the residue was extracted again with another $200 \mathrm{ml}$ of $20 \%$ ethanol. The extracts were reduced to $40 \mathrm{ml}$ at about $90{ }^{\circ} \mathrm{C}$. The concentrate was put into a $250 \mathrm{ml}$ separatory funnel and $20 \mathrm{ml}$ of diethyl ether were added and shaken. The solution layer w 3 recovered while the ether layer was discarded then $60 \mathrm{ml}$ of $n$-butanol was added. The mixture was washed twice with $10 \mathrm{ml}$ of $5 \%$ aqueous sodium chloride. The solution was evaporated in a water bath. After that, the samples were dried in the oven to a constant weight. The saponin content was calculated as $\mathrm{mg} / 100 \mathrm{~g}^{8}$

\subsection{HCN Content}

$\mathrm{HCN}$ content determination was done with the iso-nicotinic 1 id-3-methyl-1-phenyl-5-pyrazolone. The HCN was converted to cyanogen chloride with an aqueous solution of chloraf 1 ne- $T$, and then absorbed by sodium hydroxide. The reaction of the cyanogen chloride with pyridine and then with a 3-methyl-1-phenyl-5-pyrazolone reagent results in a colored complex, which was analyzed by a spectrophotometer at $638 \mathrm{~nm}^{15}$

\subsection{Statistical Analysis}

8 the mean values of multiple groups were analyzed by oneway analysis of variance (ANOVA). To determine the difference between treatments, Duncan test was conducted. $P$ value of $<0,05$ was classified as statistically significant.

\section{RESULTS}

The proximate composition (\%) and crude fiber (\%) of lindur fruits flour were presented in Table I. The study results showed that the proximate composition of the fresh lindur fruits were moisture content $(52.221 \pm 0.710) \%$, protein content $(4.433 \pm 0.066) \%$, lipid content $(0.896 \pm 0.074) \%$, ash content $(4.550 \pm 0.224) \%$, carbohydrate content $(82.266 \pm 0.438) \%$, and crude fiber $(7.870 \pm 0.247) \%$. Pre-treatments produce lindur flour with moisture content between $(10.969 \pm 0.241) \%$ to $(12.767 \pm$ $0.079) \%$, protein content $(4.027 \pm 0.411) \%$ to $(5.714 \pm 0.452) \%$, lipid content $(0.440 \pm 0.062) \%$ to $(0.932 \pm 0.099) \%$, ash content $(0.944 \pm 0.024) \%$ to $(4.364 \pm 0.469) \%$, carbohydrate content $(83.475 \pm 0.058) \%$ to $(90.824 \pm 0.836) \%$, and crude fiber content $(8.861 \pm 0.021) \%$ to $(14.770 \pm 0.063) \%$.

Fresh lindur had tannin content of $(1.221 \pm 0.007) \%$, saponin content $(0.030 \pm 0.013) \%$, and $\mathrm{HCN}$ content $(1498.907 \pm$ 10.340) ppm. The antinutritional properties of the lindur fruits flour were presented in Table II. The results showed that the lin$d u r$ fruits flour had a tannin content $(0.766 \pm 0.070$ to $1.648 \pm$

Table I. Nutritional of the lindur fruits flour.

\begin{tabular}{|c|c|c|c|c|c|c|}
\hline Sample & $\begin{array}{c}\text { Moisture } \\
\text { content (\%) }\end{array}$ & $\begin{array}{l}7 \text { Protein } \\
\text { content (\%db) }\end{array}$ & $\begin{array}{c}\text { Lipid } \\
\text { content (\%db) }\end{array}$ & $\begin{array}{c}\text { Ash } \\
\text { content (\%db) }\end{array}$ & $\begin{array}{l}\text { Carbohydrate } \\
\text { content (\%db) }\end{array}$ & $\begin{array}{c}\text { Crude } \\
\text { fiber (\%db) }\end{array}$ \\
\hline$A_{0}$ & $52.221 \pm 0.710^{a}$ & $4.433 \pm 0.066^{a}$ & $0.896 \pm 0.074^{a}$ & $4.550 \pm 0.224^{a}$ & $82.266 \pm 0.438^{a}$ & $7.870 \pm 0.247^{a}$ \\
\hline$A_{1}$ & $12.767 \pm 0.079^{b}$ & $5.265 \pm 0.026^{b}$ & $0.440 \pm 0.062^{b}$ & $0.944 \pm 0.024^{b}$ & $83.475 \pm 0.058^{b}$ & $9.872 \pm 0.042^{b}$ \\
\hline$A_{2}$ & $10.969 \pm 0.241^{c}$ & $5.714 \pm 0.452^{b}$ & $0.932 \pm 0.099^{a}$ & $3.073 \pm 0.125^{c}$ & $90.393 \pm 0.686^{c}$ & $14.770 \pm 0.063^{\circ}$ \\
\hline$A_{3}$ & $12.225 \pm 0.835^{b}$ & $4.027 \pm 0.411^{a}$ & $0.845 \pm 0.079^{a}$ & $4.364 \pm 0.469^{a}$ & $90.824 \pm 0.836^{c}$ & $14.645 \pm 0.123^{c}$ \\
\hline$A_{4}$ & $11.266 \pm 0.045^{c}$ & $5.341 \pm 0.048^{b}$ & $0.857 \pm 0.026^{a}$ & $0.948 \pm 0.033^{b}$ & $83.995 \pm 0.054^{b}$ & $8.861 \pm 0.021^{\circ}$ \\
\hline
\end{tabular}

Notes: Mean of three replications \pm standard deviation. Means in the same column and different letters are significantly different $(P<0.05)$. 
Table II. Antinutritional of the lindur fruits flour.

\begin{tabular}{lccc}
\hline Sample & Tannin content (\%) & Saponin content (\%) & $\mathrm{HCN}$ content $(\mathrm{ppm})$ \\
\hline$A_{0}$ & $1.221 \pm 0.007^{a}$ & $0.030 \pm 0.013^{a}$ & $1498.907 \pm 10.340^{a}$ \\
$A_{1}$ & $1.282 \pm 0.001^{a c}$ & $0.067 \pm 0.009^{b}$ & $202.773 \pm 16.583^{b}$ \\
$A_{2}$ & $0.766 \pm 0.070^{b}$ & $0.065 \pm 0.010^{b}$ & $231.705 \pm 6.004^{c}$ \\
$A_{3}$ & $1.358 \pm 0.002^{c}$ & $0.056 \pm 0.011^{b}$ & $489.304 \pm 12.434^{d}$ \\
$A_{4}$ & $1.648 \pm 0.002^{d}$ & $0.102 \pm 0.020^{c}$ & $375.493 \pm 10.757^{\circ}$ \\
\hline
\end{tabular}

$0.002) \%$, saponin content $(0.056 \pm 0.011$ to $0.102 \pm 0.020) \%$, and $\mathrm{HCN}$ content $(202.773 \pm 16.583$ to $489.304 \pm 12.434) \mathrm{ppm}$.

\section{DISCUSSION}

\subsection{Proximate Composition and Crude Fiber}

The moisture content of fresh lindur fruits in this study was different from the earlier reports which the moisture content of fresh 6 dur fruits was $65.18 \%$ and has been dried decreased to $9.18 \% .^{5}$ There was the significant difference in the moisture content of lindur fruits flour as affected by the different soaking agent which soaking on saturated salt solution showed the lindur fruits flour had the lowest moisture content. The moisture content in lindur fruits flour was used for microbiological spoilage to grow. ${ }^{16}$

The results showed that protein content of lindur fruit flour was lower than protein content of wheat bran $9.6 \%$, rice bran $11.8 \%$, barley bran $11.9 \%$, and oat bran $15.0 \%$ in the study Kaur et al. ${ }^{6}$ Thus, lindur fruits flour is not a good source of protein. The high protein content showed that it might offer an affordable source of protein to counteract protein malnutrition. ${ }^{17}$ The pretreatment of soaking in different solutions can increase the protein content of lindur fruits flour. According to Nurjanah et al., ${ }^{5}$ there was an increase in protein content due to the reduced moisture content, thereby increasing the proportion of protein. The lipid content of lindur fruits flour was lower than another source of carbohydrate, such as wheat bran $4.1 \%$, rice bran $19.3 \%$, barley bran $4.2 \%$, and oat bran $10.6 \%{ }^{6}$

Soaking treatment in water, saturated salt solution, and rice husk ash solution can reduce the ash content of lindur fruits content. This related to how much water can be drawn out of the lindur fruits while soaking. The water coming out of the lindur fruits carry minerals. Ash content reflects the quantity of mineral matter present in the flour. ${ }^{15}$

2 Based on research of Kaur et al., ${ }^{6}$ carbohydrate content in wheat bran $60.5 \%$, rice bran $36.6 \%$, barley bran $51.8 \%$, and oat bran $55.6 \%$. The high carbohydrate content shows that it can serve as a good source of energy. ${ }^{18}$ Differences in the nutritional composition can be influenced by the environment or habitat and species. ${ }^{19}$

The highest crude fiber was caused by the soaking lindur fruits in a saturated salt solution and $\mathrm{CaCO}_{3}$ solution. Crude fiber cannot be digested by human, it plays a useful role in providing roughage that aids digestion and reduces the accumulation of

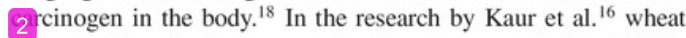
bran, rice bran, barley bran, and oat bran has a crude fiber $7.75 \%$, $11.5 \%, 14.9 \%$, and $3.31 \%$; respectively.

\subsection{Tannin Content}

When compared to other carbohydrate sources, lindur fruits flour produced higher tannin content, despite soaking. Kaur et al. ${ }^{6}$ reported that tannin content in different defatted cereals are wheat bran $2.22(\mathrm{mg} / \mathrm{g})$ or $0.222 \%$, rice bran $0.58(\mathrm{mg} / \mathrm{g})$ or $0.58 \%$, barley bran $2.73(\mathrm{mg} / \mathrm{g})$ or $2.73 \%$, and oat bran $5.17(\mathrm{mg} / \mathrm{g})$ or $0.517 \%$. The tannins are concentrated in the seeds coat, so that the de-hulling can reduce tannin content of cereals bean.

The lowest tannin content in lindur fruits flour was caused by soaking in a saturated salt solution. The tannin content reduction can be influenced by the presence of the electrolyte, such as $\mathrm{NaCl}$. It is caused due to the electrostatic force between the adsorbent surface and adsorbate ions, thereby causing adsorption of tannins. ${ }^{20}$ The reduction of tannin also because these compounds are heat labile and degrade upon heat treatment. Soaking also showed a significant reduction in tannin content. This reduction could be due to leaching of tannin into the soaked solution. ${ }^{15}$

\subsection{Saponin Content}

Lindur fruits flour in this study contains saponins higher than saponin content of fresh lindur fruits. This is in contrast with the statement of Kaur et al. ${ }^{13}$ in which the saponins can be lost due to heating because they are thermo-labile. Soaking can also lead leaching out of saponin into the water through diffusion.

The treatment of soaking in saturated salt solution and solution causes saponin content in lindur fruits flour lower than the treatment of soaking in a rice husk ash solution. This is presumably due to salt and $\mathrm{CaCO}_{3}$ have the ability to adsorpt of the saponins. Li et al. ${ }^{20}$ stated that the inorganic salts can influence the adsorption of organic compound, such as saponins.

\subsection{HCN Content}

The treatment of soaking in water, produced lindur fruits flour with lowest $\mathrm{HCN}$ content. The similar study result demonstrated by Soetan ${ }^{21}$ which phytochemicals contain (including $\mathrm{HCN}$ ) in Lablab purpureus can be reduced by soaking, heating, and boiling in water for an extended period of time. $\mathrm{HCN}$ is very volatile and very poisonous liquid, which can evaporate at $26^{\circ} \mathrm{C}$. When the temperature increases, the reduced nitrogen in $\mathrm{HCN}$ is equal to that in the formed $\mathrm{N}_{2} .{ }^{22}$

The results showed that the content of $\mathrm{HCN}$ in lindur fruits flour was higher than $\mathrm{HCN}$ content in cassava dried $(4.20 \pm 0.01)$ $\mathrm{mg} / 100 \mathrm{~g}$ or $(42 \pm 0.01) \mathrm{ppm}^{23}$ and also higher than $\mathrm{HCN}$ content in another mangrove fruits such as Avicennia marina $8.37 \mathrm{ppm}^{24}$ Nevertheless, soaking in $\mathrm{CaCO}_{3}$ solution can reduce $\mathrm{HCN}$ content in the lindur fruits by $67 \%$. It is assumed that $\mathrm{CN}$ on $\mathrm{HCN}$ binds to $\mathrm{Ca}$ on $\mathrm{CaCO}_{3}$. Tan et al. ${ }^{25}$ conducted a study to reduce of $\mathrm{HCN}$ with $\mathrm{CaO}$ at high temperature. $\mathrm{HCN}$ and $\mathrm{CaO}$ react and produce $\mathrm{CaCN}_{2}, \mathrm{CO}$, and $\mathrm{H}_{2}$.

\section{CONCLUSION}

The different soaking treatments could affect the nutritional (proximate composition and crude fiber) and antinutritional properties (tannin content and HCN content) of lindur fruit flour. The saturated salt solution soaking treatment was the best pretreatment to reduce antinutritional properties of lindur fruit flour. Lindur fruits flour with the low level of anti-nutritional components can be safe for human consumption.

The presence of antinutritional factors identified in this current study illustrated that these should not pose a problem to human health if the lindur fruit is properly processed. The pre-treatments with soaking can reduce the tannin and $\mathrm{HCN}$ content in the lindur 
fruits flour. In view of the overall proximate composition, lindur fruit can be explored as an alternative source of food.

\section{References and Notes}

1. Onrizal, Indonesian Journal of Biology 9 (2010).

2. A. M. Jacoeb, A. Abdullah, and R. Rushdi, Journal Aquatic 4 (2010)

3. A. M. Jacoeb, P. Suptijah, and Zahidah, Journals Indonesian Fishery Product Processing 16 (2013)

4. S. Sudirman, Nurjanah, and A. M. Jacoeb, International Food Research Journal 21 (2014).

5. N. Nurjanah, A. M. Jacoeb, T. Hidayat, and A. Shylina, International Journal of Plant Science and Ecology 1 (2015).

6. S. Kaur, S. Sharma, and H. P. S. Nagi, Asian Journal of Food and AgroIndustry 4 (2011).

7. P. K. Ashok and K. Upadhyaya, Journal of Pharmacognosy and Phytochemistry 1 (2012).

8. C. M. Ejikeme, C. S. Ezeonu, and A. N. Eboatu, European Scientific Journal 10 (2014).

9. H. Khan, M. A. Khan, and Abdullah, Toxicology and Industrial Health 31 (2015).

10. J. Fiallos-Jurado, J. Pollier, T. Moses, P. Arendt, N. Barriga-Medina, E. Morillo, V. Arahana, M. L. Torres, A. Goossens, and A. Leon-Reyes, Plant Science 250 (2016).

11. P. K. Uddandapu, Y. V. Rao, and K. C. Naidu, International Journal of Bioassays $5.3(2016)$.
12. P. K. Dhas, P. Chitra, S. Jayakumar, and A. R. Mary, Indian Journal of Occupational and Environmental Medicine 15 (2011).

13. S. Kaur, S. Sharma, B. N. Dar, and B. Singh, Food Sci. Technol. Int. 18 (2012)

14. $[A O A C]$ Association of Official Analytical Chemist, Official Method of Analysis of the Association of Official Analytical Chemist, 18th edn., The Association of Official Analytical Chemist, Inc., Arlington (2005)

15. P. Ning, J. Qiu, X. Wang, W. Liu, and W. Chen, Journal of Environmental P. Ning, J. Qiu, X.
Sciences 25 (2013)

16. S. I. Rafiq, S. Singh, and D. C. Saxena, Journal of Food Measurement and Characterization 10 (2016).

17. T. Shantibala, R. K. Lokeshwari, and H. Debaraj, Journal of Insect Science 14 (2014).

18. V. N. Osabor, G. E. Egbung, and P. C. Okafor, Pakistan Journal of Nutrition 7 (2008).

19. Y. Megayana, S. Subekti, and M. A. Alamsjah, Journal of Aquaculture and Fish Health 1 (2012)

20. H. Li, G. Huang, C. An, J. Hu, and S. Yang, Ind. Eng. Chem. Res. 52 (2013).

21. K. O. Soetan, African Journal of Plant Science 6 (2012).

22. M. Seredych, M. van der Merwe, and T. J. Bandosz, Carbon 47 (2009).

23. D. I. Etong and E. A. Abbah, Food Science and Quality Management 33 (2014)

24. T. D. Sulistiyati, S. Setyoyuwono, E. Y. Herawati, and Sumarno, Journal of Food Studies 2 (2013).

25. H. Tan, X. Wang, C. Wang, and T. Xu, Energy and Fuels 23 (2009)

Received: 30 September 2016. Revised/Accepted: 22 December 2016. 
Nutritional and Antinutritional Properties of lindur (Bruguiera gymnorrhiza)Fruits Flour from Different Pre-Treatments

ORIGINALITY REPORT

5

SIMILARITY INDEX
$2 \%$

INTERNET SOURCES
$3 \%$

PUBLICATIONS
$0 \%$

STUDENT PAPERS

Ping Ning, Juan Qiu, Xueqian Wang, Wei Liu, Wei Chen. "Metal loaded zeolite adsorbents for hydrogen cyanide removal", Journal of

Environmental Sciences, 2013

Publication

2 Gurkirat Kaur. "Functional properties of pasta enriched with variable cereal brans", Journal of Food Science and Technology, 02/25/2011

Publication

3 Submitted to Kenyatta University Student Paper

5 Prasad, Nagendra, Bao Yang, Kin Weng Kong, Hock Eng Khoo, Jian Sun, Azrina Azlan, Amin Ismail, and Zulfiki Bin Romli. "Phytochemicals and Antioxidant Capacity from Nypa fruticans Wurmb. Fruit", Evidence-based Complementary and Alternative Medicine, 
2013.

Publication

6 www.davidpublishing.com

7 scholarbank.nus.edu.sg

Dar, B. N., Savita Sharma, and Gulzar Ahmad

Nayik. "Effect of storage period on

physiochemical, total phenolic content and

antioxidant properties of bran enriched snacks",

Journal of Food Measurement \&

Characterization, 2016.

Publication

9 www.mdpi.com

Internet Source

10 www.ajas.info

Exclude quotes

Exclude bibliography
Off

On
Exclude matches

Off 